\title{
Biological effects of rinsing morsellised bone grafts before and after impaction
}

\author{
Gerjon Hannink • Ester Piek • Jose M. A. Hendriks • \\ Peter M. Van der Kraan • B. Willem Schreurs • \\ Pieter Buma
}

Received: 9 November 2007 /Revised: 29 November 2007 / Accepted: 2 December 2007 / Published online: 16 January 2008

(C) The Author(s) 2007

\begin{abstract}
Rinsing bone grafts before or both before and after impaction might have different effects on the incorporation of the graft. Rinsing again after impaction might negatively influence bone induction if growth factors released by impaction are washed away. We studied if transforming growth factor- $\beta \mathrm{s}$ (TGF- $\beta \mathrm{s}$ ) and bone morphogenetic proteins (BMPs) are released from the mineralised matrix by impaction and if these released growth factors induce osteogenic differentiation in human mesenchymal stem cells (hMSCs). Rinsed morsellised bone allografts were impacted in a cylinder and the escaping fluid was collected. The fluid was analysed for the presence of TGF- $\beta$ s and BMPs, and the osteoinductive capacity was tested on hMSCs. Abundant TGF- $\beta$ was present in the fluid. No BMPs could be detected. Osteogenic differentiation of hMSCs was inhibited by the fluid. Results from our study leave us only able to speculate whether rinsing grafts again after impaction has a beneficial effect on the incorporation process or not.
\end{abstract}

Résumé Laver les greffons avant et après impaction peut avoir des conséquences diverses sur l'incorporation de la

G. Hannink · B. W. Schreurs $\cdot$ P. Buma $(\bowtie)$

Orthopaedic Research Lab., Department of Orthopaedics,

Radboud University Nijmegen Medical Centre,

P.O. Box 9101, 6500 HB Nijmegen, The Netherlands

e-mail: p.buma@orthop.umcn.nl

E. Piek · J. M. A. Hendriks

Department of Applied Biology, Radboud University Nijmegen, Toernooiveld 1,

6525 ED Nijmegen, The Netherlands

P. M. Van der Kraan

Department of Experimental Rheumatology and Advanced

Therapeutics, Radboud University Nijmegen Medical Centre,

P.O. Box 9101, 6500 HB Nijmegen, The Netherlands greffe. En effet, laver à nouveau après l'impaction aura une influence négative sur l'induction osseuse car les facteurs de croissances relargués par l'impaction ont été éliminés. Nous avons étudié ainsi le facteur TGF- $\beta$ s et BMPs relargués de la matrice minérale osseuse après impaction et si ce relarguage des facteurs avaient une action d'induction ostéogénique sur la différenciation des cellules mésenchymateuses hMSCs. Pour cela, nous avons lavé l'allogreffe quand celle-ci est impactée dans un cylindre et que les fluides ont été collectés. Les fluides sont analysés pour détecter la présence de TGF- $\beta$ s et BMPSs et, les capacités d'ostéo induction sont testées sur des cellules mésenchymateuses humaines. Une quantité abondante de TGF- $\beta$ s se retrouve dans les fluides, par contre nous n'avons pas retrouvé de BMPs. La différenciation ostéogénique sur les cellules mésenchymateuses hMSCs est inhibée par ce fluide. Les résultats de ce travail nous permettent de penser que l'action de laver les greffons après impaction peut avoir un effet bénéfique ou non sur l'incorporation.

\section{Introduction}

Bone impaction grafting with a cemented prostheses is a biologically attractive technique for treating bone stock defects around failed total hip prostheses, with long-term clinical survival data available both on the acetabular and the femoral sides [8, 21].

Although the technique on the acetabular side has been well described by the original promoters [22], a dispute has been raised about the pros and cons of rinsing the allograft bone chips. Both rinsing once (before) and twice (before and after) impaction are used. However, rinsing before impaction or before and after impaction might have quite different effects on the incorporation of the grafts. 
Rinsing before impaction enhances the stability of graft reconstructions by creating a higher interparticle shear resistance [7]. Also, in more realistic acetabular testing models with bone impaction grafting, rinsing had a positive effect on the initial stability of the cemented cups $[1,25]$. In addition, the use of allografts induces an immunogenic response to the graft. Since most antigenic cells are found in the marrow, rinsing the grafts to remove blood, marrow and fat have been shown to diminish this negative aspect [10]. Bone grafts rinsed before impaction are better incorporated compared to unrinsed allografts [27].

Rinsing again after impaction is performed, however, only on the acetabular side, in the expectation of an additional effect on the initial mechanical stability through an increase in cement penetration. Although clinically practised, there is no experimental data supporting the benefit of rinsing again after impaction. It is not known how the rinsing of morsellised bone grafts again after impaction affects the incorporation process. Rinsing the grafts again after impaction might have a negative effect on bone induction if growth factors released by impaction are washed away.

By the impaction procedure, many microfractures are created, and biologically active factors in the bone matrix are, consequently, released. Recently, it was shown that a physiologically significant amount of transforming growth factor- $\beta$ (TGF- $\beta$ ) was released by the strong compression of rinsed cancellous bone blocks from femoral heads [9]. Many contradictory reports have been published on the effects of TGF- $\beta$ s on bone formation $[2,12]$, however, the effects of TGF- $\beta \mathrm{s}$ on bone graft incorporation are unknown.

Furthermore, it is not known if, other, more potent stimulators of bone induction, like bone morphogenetic proteins (BMPs), are released in physiologically relevant concentrations from the mineralised matrix during impaction. Therefore, we studied if TGF- $\beta$ s and BMPs are released in physiologically relevant concentrations from the mineralised bone matrix by firm impaction, and if these released growth factors induce osteogenic differentiation in human mesenchymal stem cells (hMSCs).

\section{Materials and methods}

\section{Production of "impaction fluid"}

Cancellous allografts were collected from five human femoral heads obtained from the authors' institutional bone bank. Swabs were taken and tested for bacterial contamination. All specimens were clear of bacterial contamination. The allografts were cut to $5 \times 5 \times 5-\mathrm{mm}$ pieces using a rongeur and were subsequently pooled. Blood and marrow were removed macroscopically by rinsing the grafts with saline for approximately $1 \mathrm{~min}$, leaving only a white bone structure. Rinsing was done using a commercially available high-pressure pulsatile lavage system (SurgiLav ${ }^{\circledR}$ Plus, Stryker Nederland BV, Waardenburg, the Netherlands). The grafts were in a sieve during rinsing. Allografts were dried overnight in a laminar flow cabinet (sterile airflow) at $4^{\circ} \mathrm{C}$.

The bone grafts were inserted into a cylinder with a diameter of $30 \mathrm{~mm}$. A piston, slightly smaller in diameter, was inserted into this cylinder. A rubber ring, sealing the piston, prevented the escape of fluid between the piston and the wall of the cylinder. Using an MTS loading device (MTS Systems Corporation, Minneapolis, MN, USA), the allografts were impacted. Fluid was evacuated through a canal in the bottom of the cylinder and were collected sterile. The applied pressure was calculated to be 12.5 MPa. The gathered fluid was centrifuged for $10 \mathrm{~min}$ at $3,000 \mathrm{rpm}$ at $4^{\circ} \mathrm{C}$. Any cellular and fatty debris was separated from the supernatant. The supernatant was called "impaction fluid."

Analysis of "impaction fluid"

TGF- $\beta 1$ and TGF- $\beta 2$ levels in the "impaction fluid" were measured by enzyme-linked immunosorbent assay (ELISA; Quantikine $^{\circledR}$, R\&D Systems Europe Ltd., Abingdon, United Kingdom) according to the manufacturer's instructions. The plate was read in an ELISA reader at $450 \mathrm{~nm}$ (Sunrise $^{\mathrm{TM}}$, Tecan Group Ltd., Männedorf, Switzerland). Experiments were performed in triplicate.

The presence of BMPs was determined using a modified BMP-selective reporter bioassay (BRE-luc) inducing luciferase expression [16]. This assay is based on 3T3 fibroblasts stably transfected with the BRE-luc reporter construct. In short, 3T3 BRE-luc cells were seeded in a density of 20,000 per well in microtitre plates in D-MEM (Gibco Invitrogen Corp., Grand Island, NY, USA) with 5\% FCS. After $24 \mathrm{~h}$, BMP-containing samples were added and the cells were incubated for a further $20 \mathrm{~h}$. Luciferase activity was quantified using the Bright-Glo ${ }^{\mathrm{TM}}$ Luciferase Assay System (Promega, Madison, WI, USA). Luminescence was measured using a plate luminometer according to the manufacturer's protocol (POLARstar Galaxy, BMG Labtech $\mathrm{GmbH}$, Offenburg, Germany). For the standard curve, serial dilutions of rhBMP-2 (R\&D Systems Europe Ltd., Abingdon, United Kingdom) to final concentrations of 0 to $100 \mathrm{ng}$ BMP-2/ml were used. The lower detection limit of this assay is $1.6 \mathrm{ng} / \mathrm{ml} \mathrm{BMP-2}$. Experiments were performed in triplicate.

Almost all members of the TGF- $\beta$ family, including BMPs, are secreted as latent complexes and need to be activated to exhibit their biological activity [28]. Therefore, 
both active and total growth factor levels were measured in order to have an impression of latent growth factor levels. The total growth factor levels were measured by activating the growth factors in the samples using hydrochloric acid and, subsequently, neutralising the samples by sodium hydroxide, according to the manufacturer's instructions.

\section{Culture study}

Human mesenchymal stem cells (Poietics ${ }^{\mathrm{TM}}$ hMSC, Cambrex Bio Science Verviers, S.p.r.l., Belgium) were cultured up to passage 7 on mesenchymal stem cell growth medium (MSCGM $^{\text {TM }}$ BulletKit $^{\circledR}$ (PT-3001), Cambrex Bio Science Verviers, S.p.r.l., Belgium). The cells were incubated in a humidified atmosphere of $92.5 \%$ air and $7.5 \% \mathrm{CO}_{2}$ at $37^{\circ} \mathrm{C}$. After primary culture, cells were detached using trypsin/ EDTA (Cambrex Bio Science Verviers, S.p.r.l., Belgium), and the cells were seeded in 96-well plates at a density of 20,000 cells $/ \mathrm{cm}^{2}$. The cells were allowed to attach overnight. After cell attachment, the cells were cultured under static conditions for 7 days. Cells were cultured on osteogenic differentiation medium (hMSC Osteogenic Differentiation BulletKit $^{\circledR}$ (PT-3002), Cambrex Bio Science Verviers, S.p.r. 1., Belgium) with and without $10^{-7} \mathrm{M}$ dexamethasone (Sigma, Chemical Co., St. Louis, MO, USA). The supernatant ("impaction fluid") was lyophilised. Subsequently, the lyophilised "impaction fluid" was resuspended in osteogenic differentiation medium (without dexamethasone), equal to the original volume of the supernatant. The hMSCs were stimulated with $5 \mathrm{ng} / \mathrm{ml}$ TGF- $\beta 1$ (rhTGF- $\beta 1$, R\&D Systems Europe Ltd., Abingdon, United Kingdom), $10^{-8} \mathrm{M}$ vitamin D3 $\left[1,25(\mathrm{OH})_{2} \mathrm{D}_{3}\right], 100 \mathrm{ng} / \mathrm{ml}$ BMP-2 (rhBMP-2, R\&D Systems Europe Ltd., Abingdon, United Kingdom) and $10 \%, 20 \%, 40 \%$ and $80 \%$ "impaction fluid." The culture medium was changed every three days. Experiments were performed in triplicate. Osteogenic differentiation medium without dexamethasone was used as the negative control, whereas osteogenic differentiation medium supplemented with dexamethasone and vitamin D3 was used as the positive control [4].

Alkaline phosphatase assay

Alkaline phosphatase (ALP) activity was measured to obtain information about the osteogenic differentiation of the cells. Medium was removed and the cell layers were washed twice with phosphate buffer solution (PBS). The cells were fixed with $4 \%$ buffered formaldehyde and washed twice with PBS again.

The substrate solution was made by adding $1 \mathrm{ml}$ of $10 \mathrm{mM} \mathrm{MgCl}_{2}$ to $10 \mathrm{ml}$ of $1 \mathrm{M}$ di-ethanol-amine (DEA) and dissolving $52.6 \mathrm{mg}$ of para-nitrophenyl phosphate (PNPP) in $10 \mathrm{ml}$ of this solution. Subsequently, $100 \mu \mathrm{l}$ of substrate solution was added to each well and the plate was incubated for $15 \mathrm{~min}$. The reaction was stopped by adding $100 \mu \mathrm{l}$ of $0.5 \mathrm{M} \mathrm{NaOH}$. The plate was read in an ELISA reader at $405 \mathrm{~nm}$ (Wallac ${ }^{\mathrm{TM}}$ VICTOR ${ }^{2} 1420$, PerkinElmer Life and Analytical Sciences, Inc., Boston, MA, USA).

Neutral red assay

A neutral red (NR) assay was performed to obtain an indication of the number of viable cells (proliferation). A $1: 1$ solution of neutral red stock $(1 \mathrm{mg} / \mathrm{ml}$ milliQ water) and $1.8 \% \mathrm{NaCl}$ solution was made and filtered. One hundred microlitres $(100 \mu \mathrm{l})$ of this solution was added to each well and the plate was incubated for $90 \mathrm{~min}$ at $37^{\circ} \mathrm{C}$. Neutral red solution was removed and the cell layers were washed twice with PBS. Subsequently, $100 \mu$ lof elution buffer $\left(0.05 \mathrm{M} \mathrm{NaH}_{2} \mathrm{PO}_{4} / 50 \% \mathrm{EtOH}\right)$ was added to each well. The plate was read in an ELISA reader at $550 \mathrm{~nm}$ (Wallac ${ }^{\mathrm{TM}}$ VICTOR $^{2} 1420$, PerkinElmer Life and Analytical Sciences Inc., Boston, MA, USA). The neutral red assay was used to correct the alkaline phosphatase assay for the number of viable cells.

\section{Results}

Analysis of "impaction fluid"

Analysis of the "impaction fluid" revealed that TGF- $\beta$ was abundant. Both TGF- $\beta 1$ and TGF- $\beta 2$ were present in the "impaction fluid" in physiologically significant amounts. The total levels of TGF- $\beta 1$ and TGF- $\beta 2$ present after activation were $5.39( \pm 1.12) \mathrm{ng} / \mathrm{g}$ bone and $1.20( \pm 0.12) \mathrm{ng} / \mathrm{g}$ bone, respectively. Before the samples were activated, an already active amount of $0.43( \pm 0.05)$ ng TGF- $\beta 1 / \mathrm{g}$ bone and 0.13 $( \pm 0.11)$ ng TGF- $\beta 2 / \mathrm{g}$ bone was measured (Fig. 1). No BMPs could be detected using the BMP-selective reporter bioassay. Luciferase expression did not exceed the detection limit of $1.6 \mathrm{ng}$ BMP-2/ml.

\section{Cell culture study}

Adding dexamethasone to the osteogenic differentiation medium caused an approximately three-fold increase in ALP activity. Vitamin D3 added to osteogenic differentiation medium supplemented with dexamethasone showed the highest induction of ALP activity, whereas the addition of $5 \mathrm{ng} / \mathrm{ml}$ TGF- $\beta 1$ strongly suppressed the induction of ALP activity. The "impaction fluid" dose-dependently suppressed the ALP activity induced by dexamethasone (Fig. 2). Both $40 \%$ and $80 \%$ "impaction fluid" showed similar suppression to $5 \mathrm{ng} / \mathrm{ml}$ TGF- $\beta 1$. 


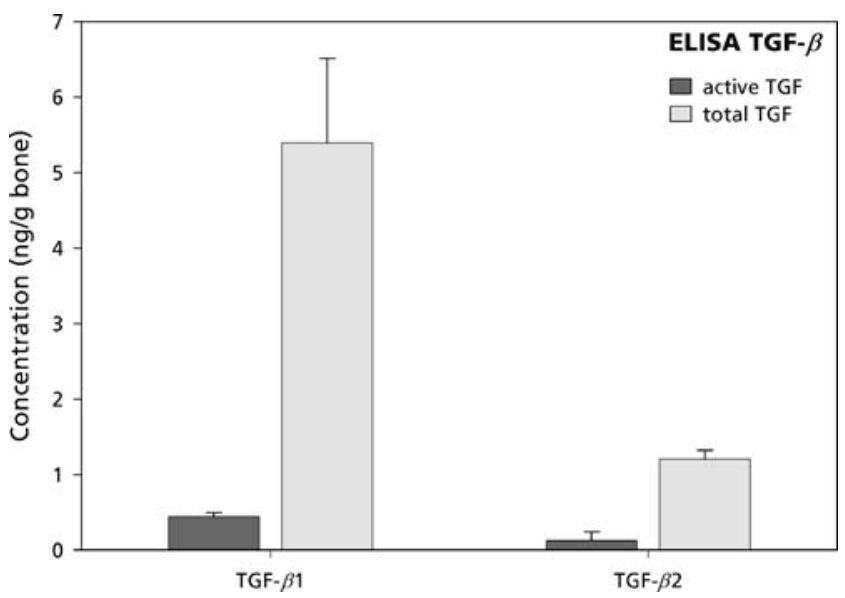

Fig. 1 Level of transforming growth factor- $\beta 1$ and $-\beta 2$ (TGF- $\beta 1$ and TGF- $\beta 2$ ) measured in the "impaction fluid." Both total and already active growth factor levels are shown. Data are mean \pm standard deviation (SD) of experiments performed in triplo

\section{Discussion}

The fracture surface created by impaction could have a growth-promoting effect by enabling the release of growth factors. Rinsing morsellised bone grafts again after impaction, therefore, might have a negative effect on bone induction if growth factors released during impaction are washed out. In our study, we examined if TGF- $\beta$ and BMPs are released from the mineralised matrix by impaction, and whether these released growth factors induce osteogenic differentiation in hMSCs.

Both TGF- $\beta 1$ and TGF- $\beta 2$ were abundantly present in "impaction fluid." Corresponding to what is seen in demineralised bone, in our study, most TGF- $\beta$ was present in a latent form. Bone grafts from five femoral heads were pooled to minimise variation to overcome possible bias. However, it should be noticed that a large variation of TGF$\beta$ exists in human bone tissue both in tissue location and between individuals [19]. Our results are in accordance with the results of Fyhrie et al. [9] who recently showed that strong mechanical compression of cancellous bone blocks from femoral heads accelerates the release of TGF$\beta 2$. In addition, they and others suggested that mechanical loading also might accelerate the release of other growth factors, like BMPs, from mineralised bone matrix [3, 9]. In our study, however, no BMPs could be detected. In the light of the overwhelming literature on BMPs in bone [23, 24], we have to conclude from this experiment that BMPs cannot be released from the mineralised matrix by impaction. The BMPs in bone are considered to be activated by demineralisation [26]; however, as described in Burwell's classical work on bone grafting, some new bone formation may be induced also from non-demineralised allografts [5]. If all BMPs are retained in the bone, this might explain the coupling of resorption and new bone formation during the incorporation of morsellised cancellous bone in bone impaction grafting [20].

Since TGF- $\beta$ is abundantly present in the "impaction fluid," it is not surprising to see a suppression of osteogenic differentiation with an increasing concentration of "impaction fluid" in our culture experiment. TGF- $\beta$ is known to inhibit the ALP expression of mesenchymal stem cells (MSCs), even when these cells are stimulated with BMPs $[12,17]$. In contrast to BMPs, TGF- $\beta$ is unable to induce osteogenesis in mesenchymal pluripotent cells [12, 14]. From this perspective, it seems that rinsing bone grafts again after impaction might even be beneficial if TGF- $\beta$ is washed away.

Data from numerous in vitro experiments have demonstrated the role of TGF- $\beta$ in every stage of bone formation $[6$, 12]. Despite conflicting results, most data support the following model [12]: TGF- $\beta$ increases bone formation in vitro mainly by recruiting osteoblast progenitors and stimulating their proliferation, thus, expanding the pool of committed osteoblasts, in addition to promoting the early stages of differentiation (bone matrix production). On the
Fig. 2 Data from cell culture Human mesenchymal stem cells (hMSCs) were cultured with and without dexamethasone. As a measure for osteogenic differentiation, alkaline phosphatase activity (ALP) was corrected for the number of viable cells (NR). Data are mean \pm SD of experiments performed in triplicate

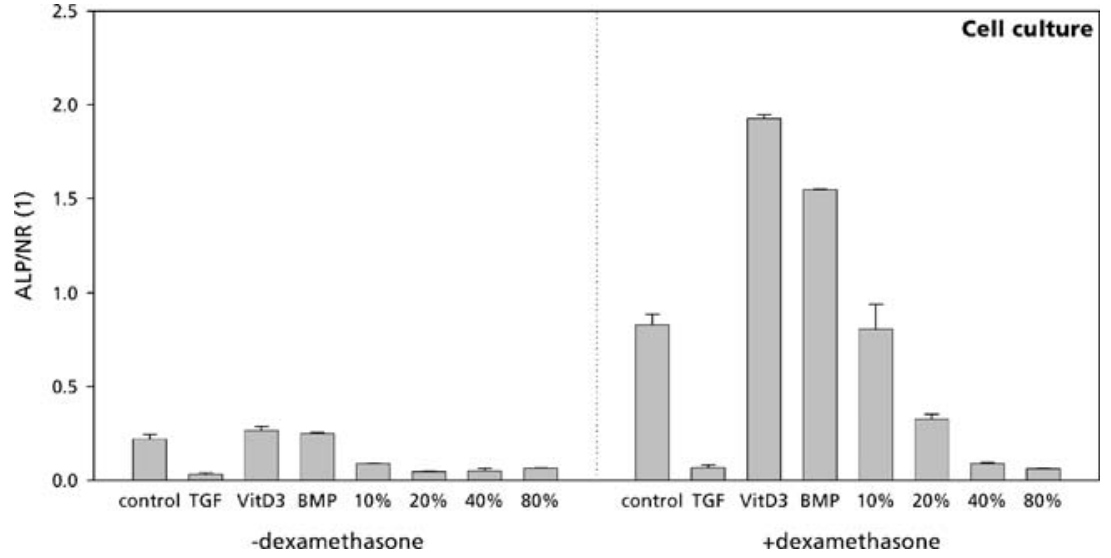


other hand, it blocks later phases of differentiation and mineralisation. These later stages are regulated by other growth factors, like BMPs. In other words, TGF- $\beta$ generally inhibits the mineralisation of the matrix it helps to produce.

However, TGF- $\beta$ not only modulates bone formation, but it can also stimulate osteoclast recruitment, formation and function $[11,15]$. Bone resorption is more detrimental for the outcome of impaction grafting than just suppression or lack of bone formation, because resorption may compromise implant fixation $[13,18]$. In addition, little or no BMPs from bone can be released prior to demineralisation. Only biological remodelling might free these factors (BMPs) to stimulate bone formation. Therefore, removing the excess of TGF- $\beta$ from bone grafts might be a useful procedure.

On the contrary, TGF- $\beta$ released after impaction might, indeed, be beneficial at an early stage postoperatively when chemotactic and proliferative signals might be needed. Furthermore, TGF- $\beta$ promotes the early stages of osteoblast differentiation. However, the fluid released by the impaction procedure in clinical surgery will, probably, only be in situ for a short period of time at the very early postoperative stage, when osteoblast differentiation is not relevant.

It should be noticed that results obtained in vitro are often not in line or even contradictory to in vivo observations. In vivo, the presence of other growth factors, cytokines and hormones in the bone environment and the environment itself determine the exact outcome of TGF- $\beta$ function.

In summary, by rinsing morsellised bone grafts again after impaction, growth factors (TGF- $\beta$ s) released during impaction are washed out. Although TGF- $\beta$ appears to be a potent stimulator of chemotaxis and the proliferation of osteoblasts, but also of osteoclast recruitment, formation and bone resorption, more potent stimulators of bone formation (BMPs) are not released from a mineralised matrix during impaction. To our knowledge, there is only one study reporting in vivo data on the effects of rinsing and the impaction of morsellised bone grafts on bone ingrowth [27]. Rinsing before impaction increased bone ingrowth in the allograft group to approach that of autografts. However, rinsing after impaction did not additionally alter bone ingrowth. The results from our study, and the dual effects of TGF- $\beta$ reported in the literature, leave us only able to speculate whether rinsing grafts again after impaction has a beneficial effect on the incorporation process.

Acknowledgement We thank Dr. P. ten Dijke for kindly providing the BRE-luc reporter construct.

Open Access This article is distributed under the terms of the Creative Commons Attribution Noncommercial License which permits any noncommercial use, distribution, and reproduction in any medium, provided the original author(s) and source are credited.

\section{References}

1. Arts JJ, Verdonschot N, Buma P, Schreurs BW (2006) Larger bone graft size and washing of bone grafts prior to impaction enhances the initial stability of cemented cups: experiments using a synthetic acetabular model. Acta Orthop 77:227-233

2. Aspenberg P, Jeppsson C, Wang JS, Boström M (1996) Transforming growth factor beta and bone morphogenetic protein 2 for bone ingrowth: a comparison using bone chambers in rats. Bone 19:499-503

3. Aspenberg P, Tägil M, Kristensson C, Lidin S (1996) Bone graft proteins influence osteoconduction. A titanium chamber study in rats. Acta Orthop Scand 67:377-382

4. Boyan BD, Schwartz Z, Swain LD (1992) In vitro studies on the regulation of endochondral ossification by vitamin D. Crit Rev Oral Biol Med 3:15-30

5. Burwell RG (1964) Studies in the transplantation of bone. VII. The fresh composite homograft-autograft of cancellous bone-an analysis of factors leading to osteogenesis in marrow transplants and in marrow-containing bone grafts. J Bone Joint Surg Br $46: 110-140$

6. Cho TJ, Gerstenfeld LC, Einhorn TA (2002) Differential temporal expression of members of the transforming growth factor beta superfamily during murine fracture healing. J Bone Miner Res 17:513-520

7. Dunlop DG, Brewster NT, Madabhushi SPG, Usmani AS, Pankaj P, Howie CR (2003) Techniques to improve the shear strength of impacted bone graft: the effect of particle size and washing of the graft. J Bone Joint Surg Am 85:639-646

8. Francés A, Moro E, Cebrian JL, Marco F, García-López A, Serfaty D, López-Durán L (2007) Reconstruction of bone defects with impacted allograft in femoral stem revision surgery. Int Orthop 31:457-464

9. Fyhrie DP, Yeni YN, Lin DL, Gibson G (2001) Mechanical stress driven release of TGF- $\beta 2$ from mineralized cancellous bone. Trans Orthop Res Soc 47:239

10. Hirn MY, Salmela PM, Vuento RE (2001) High-pressure saline washing of allografts reduces bacterial contamination. Acta Orthop Scand 72:83-85

11. Itonaga I, Sabokbar A, Sun SG, Kudo O, Danks L, Ferguson D, Fujikawa Y, Athanasou NA (2004) Transforming growth factor-beta induces osteoclast formation in the absence of RANKL. Bone 34:57-64

12. Janssens K, ten Dijke P, Janssens S, Van Hul W (2005) Transforming growth factor-beta 1 to the bone. Endocr Rev $26: 743-776$

13. Kärrholm J, Hourigan P, Timperley J, Razaznejad R (2006) Mixing bone graft with OP-1 does not improve cup or stem fixation in revision surgery of the hip: 5-year follow-up of 10 acetabular and 11 femoral study cases and 40 control cases. Acta Orthop 77:39-48

14. Katagiri T, Yamaguchi A, Komaki M, Abe E, Takahashi N, Ikeda T, Rosen V, Wozney JM, Fujisawa-Sehara A, Suda T (1994) Bone morphogenetic protein-2 converts the differentiation pathway of $\mathrm{C} 2 \mathrm{C} 12$ myoblasts into the osteoblast lineage. J Cell Biol 127:1755-1766

15. Koo KT, Susin C, Wikesjö UM, Choi SH, Kim CK (2007) Transforming growth factor-betal accelerates resorption of a calcium carbonate biomaterial in periodontal defects. J Periodontol 78:723-729

16. Korchynskyi O, ten Dijke P (2002) Identification and functional characterization of distinct critically important bone morphogenetic protein-specific response elements in the Id1 promoter. $\mathrm{J}$ Biol Chem 277:4883-4891

17. Maeda S, Hayashi M, Komiya S, Imamura T, Miyazono K (2004) Endogenous TGF-beta signaling suppresses maturation of osteoblastic mesenchymal cells. EMBO J 23:552-563 
18. McGee MA, Findlay DM, Howie DW, Carbone A, Ward P, Stamenkov R, Page TT, Bruce WJ, Wildenauer CI, Toth C (2004) The use of OP-1 in femoral impaction grafting in a sheep model. $\mathrm{J}$ Orthop Res 22:1008-1015

19. Pfeilschifter J, Diel I, Scheppach B, Bretz A, Krempien R, Erdmann J, Schmid G, Reske N, Bismar H, Seck T, Krempien B, Ziegler R (1998) Concentration of transforming growth factor beta in human bone tissue: relationship to age, menopause, bone turnover, and bone volume. J Bone Miner Res 13:716-730

20. Schimmel JW, Buma P, Versleyen D, Huiskes R, Slooff TJ (1998) Acetabular reconstruction with impacted morselized cancellous allografts in cemented hip arthroplasty: a histological and biomechanical study on the goat. J Arthroplasty $13: 438-448$

21. Schreurs BW, Bolder SB, Gardeniers JW, Verdonschot N, Slooff TJ, Veth RP (2004) Acetabular revision with impacted morsellised cancellous bone grafting and a cemented cup. A 15- to 20-year follow-up. J Bone Joint Surg Br 86:492-497

22. Slooff TJ, Huiskes R, van Horn J, Lemmens AJ (1984) Bone grafting in total hip replacement for acetabular protrusion. Acta Orthop Scand 55:593-596

23. Solheim E (1998) Growth factors in bone. Int Orthop 22:410-416

24. Solheim E (1998) Osteoinduction by demineralised bone. Int Orthop 22:335-342

25. Ullmark G (2000) Bigger size and defatting of bone chips will increase cup stability. Arch Orthop Trauma Surg 120:445-447

26. Urist MR (1965) Bone: formation by autoinduction. Science 150:893-899

27. van der Donk S, Weernink T, Buma P, Aspenberg P, Slooff TJ, Schreurs BW (2003) Rinsing morselized allografts improves bone and tissue ingrowth. Clin Orthop Relat Res 408:302-310

28. Wozney JM (2002) Overview of bone morphogenetic proteins. Spine 27(Suppl):2-8 